Pesq. Vet. Bras. 37(12):1401-1404, dezembro 2017 DOI: $10.1590 / \mathrm{S} 0100-736 \mathrm{X} 2017001200007$

\title{
Embryonic death and abortion in goats caused by ingestion of Amorimia septentrionalis ${ }^{1}$
}

\author{
Layze C.A. da Silva ${ }^{2 *}$, Danielle A. do N. Pessoa², José R.G. Lopes ${ }^{2}$, José R.S. dos \\ Santos ${ }^{2}$, Robério G. Olinda ${ }^{2}$ and Franklin Riet-Correa ${ }^{3}$
}

\begin{abstract}
Silva L.C.A., Pessoa D.A.N., Lopes R.G., Santos J.R.S., Olinda R.G. \& Riet-Correa F. 2017. Embryonic death and abortion in goats caused by ingestion of Amorimia septentrionalis. Pesquisa Veterinária Brasileira 37(12):1401-1404. Departamento de Microbiologia Veterinária e Departamento de Patologia Veterinária, Universidade Federal de Campina Grande, Av. Universitária s/n, Bairro Santa Cecília, Patos, PB 58700-970, Brazil. E-mail: layze.cilmara@hotmail.com

Amorimia spp. are sodium monofluoroacetate (MFA) containing plants causing sudden death in ruminants. In a previous study, Amorimia rigida caused abortion in one of the five pregnant sheep that received the plant suggesting that it may cause reproductive losses. This work aimed to study the embryotoxic and fetotoxic effects of Amorimia septentrionalis in goats in the Brazilian northeastern semi-arid region. The effects of $A$. septentrionalis on pregnancy were studied in 16 goats, divided into four groups according to their gestational period. In Groups 1, 2 and 3 the administration of A. septentrionalis at the daily dose of $5 \mathrm{~g}$ of leaves per kg body weight was started on the 18th, 36th and 93th days of gestation, respectively. Goats from Group 4 did not ingest the plant. When the goats presented severe signs of poisoning the administration of the plant was suspended. Groups 1, 2 and 3 ingested the plant for $7.25 \pm 2.87,9.25 \pm 2.21$ and $12.50 \pm 0.57$ days, respectively. All the goats recovered 7-12 days after the end of the administration of the plant. In Group 1, all the goats had embryonic death $6.25 \pm 3.59$ days after the end of the ingestion of the plant. In Group 2, three goats aborted at 53, 54 and 78 days of gestation. Two goats from Group 3 gave birth normally and the other two aborted at 114 and 111 days of gestation. It is concluded that Amorimia septentrionalis is a sodium monofluoracetate-containing plant that causes embryonic deaths and abortions in goats that ingest non-lethal doses of the plant.
\end{abstract}

INDEX TERMS: Poisonous plants, abortion, goats, Amorimia septentrionalis, plant poisoning, embryonic losses, sodium monofluoroacetate.

RESUMO.- [Mortalidade embrionária e abortos em cabras causados pela ingestão de Amorimia septentrionalis.] Amorimia spp. são plantas que contém monofluoroacetato de sódio (MFA), responsáveis por causar morte súbita em ruminantes. Em estudo prévio, Amorimia rigida causou aborto em uma de cinco ovelhas prenhas que receberam a planta, sugerindo que pode causar perdas reprodutivas. Este trabalho teve como objetivo estudar os efeitos embriotóxicos e fetotóxicos de Amorimia septentrionalis em caprinos na região

\footnotetext{
${ }^{1}$ Received on March 27, 2017.

Accepted for publication on April 28, 2017.

${ }^{2}$ Departamento de Microbiologia Veterinária e Departamento de Patologia Veterinária, Universidade Federal de Campina Grande (UFCG), Patos, PB 58700-000, Brazil *Corresponding author: layze.cilmara@hotmail.com

${ }^{3}$ National Institute of Agricultural Research (INIA), La Estanzuela, Casilla de Correo, 68033 Colonia, Uruguay.
}

semi-árida nordestina brasileira. Os efeitos de A. septentrionalis na prenhez foram estudados em 16 cabras, divididos em quatro grupos de acordo com seu período gestacional. Nos grupos 1, 2 e 3 a administração de A. septentrionalis foi diária, na dose de $5 \mathrm{~g}$ de folhas por $\mathrm{kg}$ de peso corporal, iniciada nos dias 18, 36 e 93 da gestação, respectivamente. As cabras do grupo 4 não ingeriram a planta. Quando as cabras apresentavam sinais severos de intoxicação suspendia-se a administração da planta. Os grupos 1, 2 e 3 ingeriram a planta por $7,25 \pm 2,87,9,25 \pm 2,21$ e $12,50 \pm 0,57$ dias, respectivamente. Todas as cabras se recuperaram 7-12 dias após o final da administração da planta. No grupo 1 , todas as cabras apresentaram quadros de mortalidade embrionária 6,25 $\pm 3,59$ dias após o término da ingestão da planta. No grupo 2 , três cabras abortaram aos 53, 54 e 78 dias de gestação. Duas cabras do Grupo 3 deram à luz normalmente e as outras duas aborta- 
ram aos 114 e 111 dias de gestação. Conclui-se que Amorimia septentrionalis é uma planta que contém monofluoroacetato de sódio e pode ocasionar mortes embrionárias e abortos em cabras que ingerem doses não letais da planta.

TERMOS DE INDEXAÇÃO: Plantas tóxicas, aborto, caprinos, Amorimia septentrionalis, intoxicação por planta, perdas embrionárias, monofluoroacetato de sódio.

\section{INTRODUCTION}

In Brazil, several toxic plant species are responsible for causing abortion in ruminants including Aspidosperma pyrifolium, Ateleia glazioviana, Enterolobium contortisiliquum, Stryphnodendron coriaceum, Stryphnodendron obovatum, Stryphnodendron fissuratum, Tetrapterys acutifolia, and Tetrapterys multiglandulosa (Riet-Correa et al. 2011). In addition to abortions, some plant species may cause embryonic death and malformations including Mimosa tenuiflora (Pimentel et al. 2007, Dantas et al. 2012) and Caesalpinia pyramidalis (Reis et al. 2016).

The monofluoroacetate (MFA) containing plant Amorimia septentrionalis is responsible for causing sudden death associated with exercise in goats, sheep and cattle. In Brazil the MFA-containing plants, including Palicourea spp. and Arrabidaea spp., cause nearly 500.000 cattle deaths annually (Pessoa et al. 2013). In a recent study, $A$. rigida caused abortion in one of the five pregnant sheep that received the plant (Vasconcelos et al. 2008) suggesting that it may cause reproductive losses. This work aimed to study the embryotoxic and fetotoxic effects of $A$. septentrionalis in goats in the Brazilian northeastern semi-arid region.

\section{MATERIALS AND METHODS}

Sixteen crossbred goats were divided into 4 groups of 4 animals each. The goats were submitted to ultra-sonographic examination for the negative diagnosis of gestation. After that, they were hosted in two stalls with 8 goats and one buck each for breeding purposes. Each male was marked with red paint on the chest and when the goats were marked, the mating date was registered. After mating, ultra-sonographic examination was carried out twice a week to confirm the gestation. After being pregnant, the goats were hosted in individual stalls and randomly distributed into one of the four experimental groups.

In Groups 1, 2 and 3 the administration of Amorimia septentrionalis was started on the 18th (organogenesis phase), 36th (fetal phase) and 93th days of gestation, respectively. The green leaves were administered daily at the dose of $5 \mathrm{~g}$ per $\mathrm{kg}$ body weight $(\mathrm{g} / \mathrm{kg})$. To the goats that did not ingest the plant voluntarily, the plant was administered orally by putting small amounts of leaves on their mouth. When the goats presented severe signs of intoxication (jugular engorgement, venous pulse, obtundation, reluctance to move, muscular tremors, motor incoordination, vocalization and sternal recumbence) the administration of the plant was suspended. The goats from Group 4 (control) did not receive the plant during pregnancy.

Amorimia septentrionalis was collected in the municipality of Teixeira (S $7^{\circ} 12.24^{\prime} 037^{\circ} 15.11^{\prime}$; altitude of $749 \mathrm{~m}$ ), located in the State of Paraíba. The average concentration of monofluoroacetate (MFA) determined in 20 samples of the plant was of $0.002 \pm 0.0009 \%$ (Lee et al. 2012).

In all the experimental period, before the administration of the plant, the goats were observed and the cardiac and respira- tory frequency, ruminal movement and the rectal temperature were measured. After the administration of the plant, the goats were moved around for 10 minutes and after the exercise, a new measuring of the previously mentioned parameters was carried.

In cases of abortion, the blood serum of the goats was tested for Brucella sp. using the plate agglutination technique with buffered acidified antigen (Card-test) and for the detection of Anti-Toxoplasma gondii antibodies by the indirect immunofluorescence test (IIFT), using the dilution of 1:64 as a cutting point (Camargo 1974). These tests were carried out in paired samples; the first after the confirmation of the abortion and the second 15 days after. For the identification of T. gondii, samples of the brain, lung, and placenta of the aborted animals were inoculated in rats (Dubey 1998). Necropsies were performed on the aborted fetuses. For histopathology examination, samples of the brain and organs of the abdominal and thoracic cavities were fixed in 10\% buffered formalin, routinely processed for histology, and stained by the hematoxylin and eosin (HE) technique. This experiment was approved by the ethics committee on animal experimentation at the Federal University of Campina Grande (Protocol CEP 69-2013).

\section{RESULTS}

The goats of Group 1 developed mild clinical signs (tachycardia and tachypnea) after $2.75 \pm 0.95$ days of plant consumption. After $7.25 \pm 2.87$ days, the clinical signs become severe and the plant administration was suspended. The consumption of $A$. septentrionalis was of $36.25 \pm 14.36 \mathrm{~g} / \mathrm{kg}$. Embryonic death was verified in all the goats, $6.25 \pm 3.59$ days after the end of the ingestion of the plant. The gestational age of the embryos was of $31.5 \pm 3.51$ days.

In Group 2, the goats presented mild clinical signs of intoxication $4 \pm 1.15$ days after starting of the administration of the plant. The administration was suspended when the signs became severe $(9.25 \pm 2.21$ days). The consumption of $A$. septentrionalis was of $46.25 \pm 11.08 \mathrm{~g} / \mathrm{kg}$. Three goats aborted one kid each on the $53^{\text {th }}, 54^{\text {th }}$ and $78^{\text {th }}$ days of gestation, $15.66 \pm 12.5$ days after the end of the ingestion of the plant. One goat gave birth to a full-term healthy kid. The goats of Group 3 developed mild clinical signs of intoxication $8 \pm 1.41$ days after starting the ingestion of $A$. septentrionalis. The plant administration was stopped on day $12.5 \pm 0.57$ when clinical signs became severe, after the consumption of $62.5 \pm 2.88 \mathrm{~g} / \mathrm{kg}$. Two goats gave birth to full-term viable kids and the other two aborted (a goat aborted a fetus on day 114 of gestation and another goats aborted two fetuses on day 111 of gestation. All goats from Groups 1-3 recovered from the clinical signs and reproductive disorders. In the goats of Group 4 (control) any reproductive disorder was observed during the gestational period and the goats gave birth to full-term healthy kids. Three goats gave birth one kid each and the others kidded two kids each. Details on the amount of $A$. septentrionalis ingested, beginning and duration of the clinical signs and occurrence of embryonic death or abortion in goats of the four groups are in Table 1 and Figure 1.

At necropsy of the fetuses from Groups 1 and 2 there were paleness of the mucosae and hairless skin. The fetuses showed a mild degree of autolysis with mild amounts of reddish liquid in the thoracic and abdominal cavities. The lungs were diffusely pale and with a shiny pleural surface. The liver was enlarged and diffusely pale. The heart 
Table 1. Gestational age, amount of Amorimia septentrionalis ingested, beginning and duration of the clinical signs and occurrence of embryonic death or abortion in goats of Groups 1, 2, 3 and 4 (control)

\begin{tabular}{|c|c|c|c|c|c|c|}
\hline \multirow[t]{2}{*}{ Group \Goat } & \multirow{2}{*}{$\begin{array}{l}\text { Gestational day } \\
\text { at the start of } \\
\text { the ingestion }\end{array}$} & \multicolumn{2}{|c|}{ Plant ingestion } & \multicolumn{2}{|c|}{ Clinical signs } & \multirow{2}{*}{$\begin{array}{l}\text { Outcome } \\
\text { Day of abortion or } \\
\text { embryonic death }\end{array}$} \\
\hline & & $\begin{array}{l}\text { Days of } \\
\text { ingestion }\end{array}$ & $\begin{array}{c}\text { Total dose } \\
\mathrm{g} \backslash \mathrm{kg}\end{array}$ & $\begin{array}{l}\text { Onset } \\
\text { (day) }\end{array}$ & $\begin{array}{c}\text { Duration } \\
\text { (days) }\end{array}$ & \\
\hline \multicolumn{7}{|l|}{ Group 1} \\
\hline Goat 1 & 18 & 9 & 45 & 22 & 5 & 34 \\
\hline Goat 2 & 18 & 3 & 15 & 20 & 5 & 29 \\
\hline Goat 3 & 18 & 8 & 40 & 21 & 7 & 35 \\
\hline Goat 4 & 18 & 9 & 45 & 20 & 7 & 28 \\
\hline \multicolumn{7}{|l|}{ Group 2} \\
\hline Goat 5 & 36 & 10 & 50 & 41 & 5 & 53 \\
\hline Goat 6 & 36 & 8 & 40 & 41 & 6 & 54 \\
\hline Goat 7 & 36 & 12 & 60 & 39 & 7 & 78 \\
\hline Goat 8 & 36 & 7 & 35 & 39 & 5 & Kidded normally \\
\hline \multicolumn{7}{|l|}{ Group 3} \\
\hline Goat 9 & 93 & 12 & 60 & 100 & 6 & Kidded normally \\
\hline Goat 10 & 93 & 13 & 65 & 101 & 7 & Kidded normally \\
\hline Goat 11 & 93 & 13 & 65 & 103 & 8 & 114 \\
\hline Goat 12 & 93 & 12 & 60 & 100 & 6 & 111 \\
\hline \multicolumn{7}{|l|}{ Group 4} \\
\hline Goat 13 & & Control & Kidded normally & & & \\
\hline Goat 14 & & Control & Kidded normally & & & \\
\hline Goat 15 & & Control & Kidded normally & & & \\
\hline Goat 16 & & Control & Kidded normally & & & \\
\hline
\end{tabular}
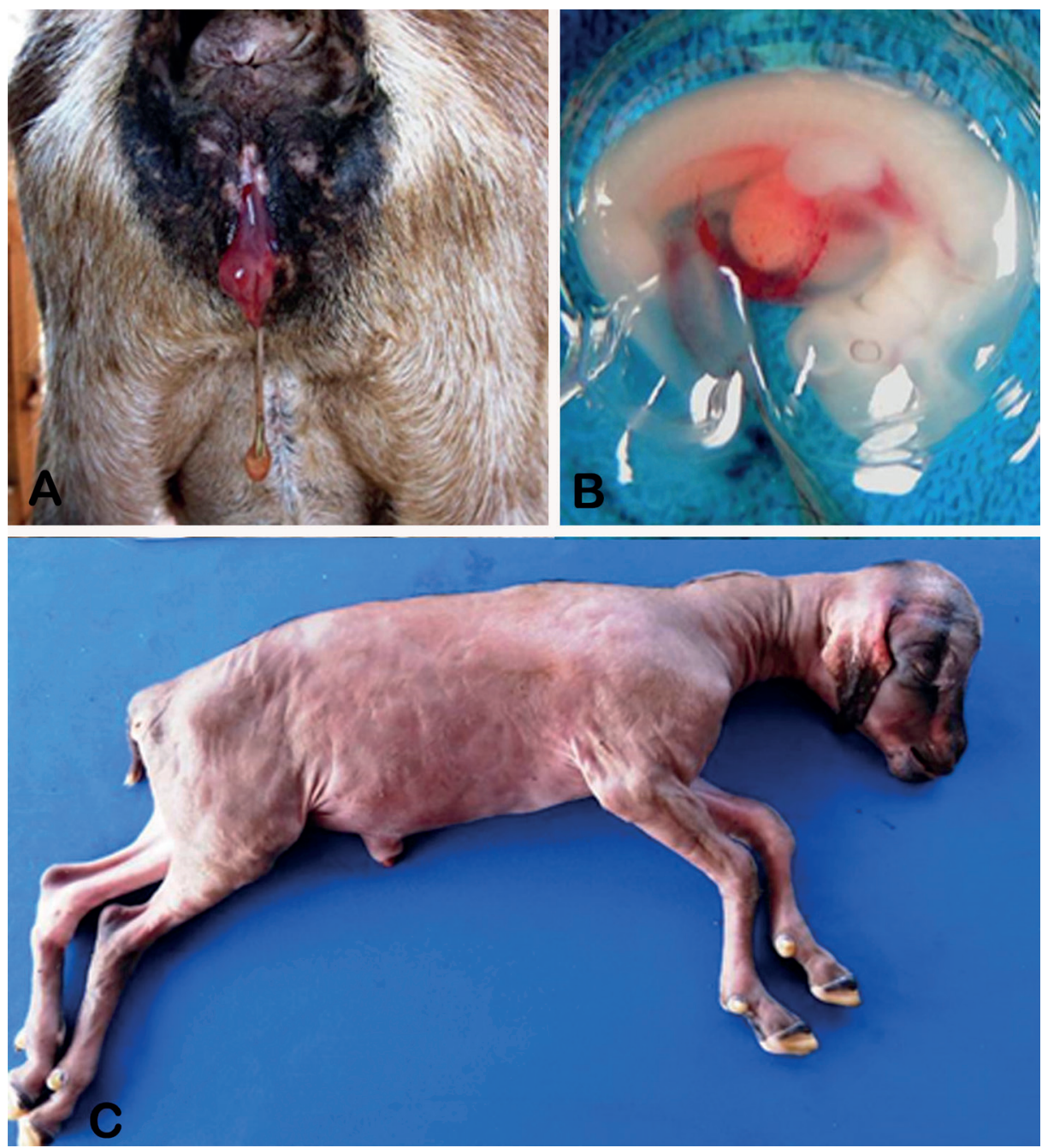

Fig.1. (A) Goat 3 showing embryonic loss on day 35 of gestation, after the consumption of Amorimia septentrionalis from day 18 th to day 25th of gestation. (B) A 29-day-old embryo prevenient from Goat 2. (C) A 111-day-old fetus aborted by Goat 12. 
presented a discreet pallor in the epicardial surface and in the brain there was hyperemia of the leptomeninges. Lesions were not observed in other organs. On the histology, the lungs had moderate pulmonary edema and congestion. The liver showed moderate diffuse hepatocellular degeneration. A diffuse congestion was observed in the brain.

The serological tests of the goats for brucellosis and toxoplasmosis were negative, and T. gondii was not isolated in the mice inoculated with tissue samples from the fetuses.

\section{DISCUSSION}

Amorimia septentrionalis poisoning causes sudden death, with clinical signs triggered by exercise in ruminants (Tokarnia et al. 2012). It has been also associated with cardiac fibrosis in bovines (Albuquerque et al. 2014). The results of this trial show that, at least in animals that show clinical signs of poisoning and recovered, this plant poisoning may cause embryonic deaths and abortions. In the later, the autolysis observed in the fetuses suggests that the abortion occurred because of fetal death. It is probable that embryonic losses and abortions occur because the embryo and the fetus are more susceptible to the monofluoroacetate (MFA) than adult goats. Therefore, in non-lethal poisoning in pregnant goats, the recovery of the dam may be followed by embryonic loss or abortion.

Abortions and embryonic losses caused by the consumption of MFA-containing plants had not been previously reported. One of the characteristics of sudden deaths caused by MFA-containing plants is that it is very unlikely that the animals recover; however, in the intoxication by Amorimia spp. it is reported the recovery of up to o $50 \%$ of the affected animals (Medeiros et al. 2002). It is probable that this relatively low lethality is due to the low concentrations of MFA in Amorimia spp. (0.0007\%-0.02\%) (Lee et al. 2012). In most cases of poisoning by Palicourea spp., which contains larger quantities of MFA $(0.21-0.24 \%$ for $P$. marcgravii and $0.09 \%$ in P. aeneofusca) (Lee et al. 2012), the animals do not recover. They died after showing clinical signs for a few minutes or may be found dead without presenting any clinical manifestation (Tokarnia et al. 2012).

Another mechanism of abortion is observed in poisoning by prussic acid contained in Pinus ponderosa, which causes a premature birth induced because of the alteration of the placental circulation and fetal hypoxia (Christenson et al. 1993). This process is apparently also the cause of the abortion by Aspidosperma pyrifolium (Medeiros et al. 2004). In contrast with the autolysis observed in the fetuses aborted by the consumption of $A$. septentrionalis, in cases of premature birth there is no autolysis of the fetuses.

Embryonic death was observed in all goats that received the plant during embryogenesis, before 36 days of gestation; however, only 5 of the 8 goats that ingested the plant during the fetal period aborted. The high rate of embryonic death may be due to the higher sensitivity of the embryo than the fetus to the MFA. The embryo is more susceptible than the fetus to the environmental or genetic agents and the susceptibility of the fetus decreases with the age, being more susceptible during organogenesis (Bernardi 2002, Sinowatz 2010).

\section{CONCLUSION}

It is concluded that Amorimia septentrionalis is an embryotoxic and fetototoxic plant, which may cause embryonic death and abortion in goats in the Brazilian semi-arid region. It is suggested that the embryonic death or abortion occur when the goats ingest non-lethal doses of MFA, that kills the embryo or the fetus, which are more susceptible to MFA that their dams.

Acknowledgements.- This research was funded by the National Institute of Science and Technology (INCT) for the Control of Poisoning by Plants, grant CNPq 573534/2008-0.

Conflict of interest.- The authors declare that they do not have any conflict of interest.

\section{REFERENCES}

Albuquerque S.S.C., Rocha B.P., Almeida V.M., Oliveira J.S., Riet-Correa F., Lee S.T., Neto J.E. \& Mendonça F.S. 2014. Fibrose cardíaca associada à intoxicação por Amorimia septentrionalis em bovinos. Pesq. Vet. Bras. 34:433-437.

Bernardi M.M. 2002. Exposição aos medicamentos durante o período perinatal, p.692-699. In: Spinosa H.S., Gorniak S.L. \& Bernardi M.M. (Eds), Farmacologia Aplicada à Medicina Veterinária. $33^{\mathrm{a}}$ ed. Guanabara Koogan, Rio de Janeiro, RJ. 752p.

Camargo M.E. 1974. Introdução as técnicas de imunofluorescência. Revta Bras. Patol. Clín. 10:143-171.

Christenson L.K., Short R.E., Farley D.B. \& Ford S.P. 1993. Effects of ingestion of pine needles (Pinus ponderosa) by late pregnant beef cows on potential sensitive Caz+ channel activity of caruncular arteries. J. Reprod. Fertil. 98:301-306.

Dantas A.F.M., Riet-Correa F., Medeiros R.M.T., Lopes J.R., Gardner D.R., Panter K. \& Mota R.A. 2012. Embryonic death in goats caused by the ingestion of Mimosa tenuiflora. Toxicon 59:555-557.

Dubey J.P. 1998. Toxoplasmosis, sarcocystosis, isosporosis, and cyclosporosis. In: Palmer S.R., Soulsbly E.J.L., Simpson D.J.H. (Eds), Zoonosis. Oxford University Press, Oxford, p.579-697.

Lee S.T., Cook D., Riet-Correa F., Pfister J.A., Anderson W.R., Lima F.G. \& Gardner D.R. 2012. Detection of monofluoroacetate in Palicourea and Amorimia species. Toxicon 60:791-796.

Medeiros R.M.T., Geraldo Neto S.A., Barbosa R.C., Lima E.F. \& Riet-Correa F. 2002. Sudden death caused by Mascagnia rigida in cattle in Paraíba, Northeastern Brazil. Vet. Human Toxicol. 44:286-288.

Medeiros R.M.T., Neto S.A.G., Riet-Correa F., Schild A.L. \& Sousa N.L. 2004. Mortalidade embrionária e abortos em caprinos causados por Aspidosperma pyrifolium. Pesq. Vet. Bras. 24:42-43.

Pessoa C.R.M., Medeiros R.M.T. \& Riet-Correa F. 2013. Importância econômica, epidemiologia e controle das intoxicações por plantas no Brasil. Pesq. Vet. Bras. 33:752-758.

Pimentel L.A., Riet-Correa F., Gardner D., Panter K.E., Dantas A.F.M., Medeiros R.M.T., Mota R.A. \& Araújo J.A.S. 2007. Mimosa tenuiflora as a cause of malformations in ruminants in the northeastern Brazilian semiarid rangelands. Vet. Pathol. 44:928-931.

Reis S.D.S., Oliveira R.S., Marcelino S.A.C., Macêdo J.T.S.A., Riet-Correa F., Pimentel L.A. \& Pedroso P.M.O. 2016. Congenital malformations and other reproductive losses in goats due to poisoning by Poincianella pyramidalis (Tul.) L.P. Queiroz (=Caesalpinia pyramidalis Tul.). Toxicon 118:91-94.

Riet-Correa F., Medeiros R.M. \& Schild A.L. 2011. A. review of poisonous plants that cause reproductive failure and malformations in the ruminants of Brazil. J. Appl. Toxicol. 32:245-254.

Sinowatz F. 2010. Teratology, p.339-382 In: Hyttel P., Sinowatz F. \& Vejlsted M. (Eds), Essential of Domestic Animal Embryology. Elsevier, China.

Tokarnia C.H., Brito M.F., Barbosa J.D., Döbereiner J. \& Peixoto P.V. 2012. Plantas Tóxicas do Brasil. $2^{2}$ ed. Helianthus, Rio de Janeiro. 586p.

Vasconcelos J.S., Riet-Correa F., Dantas A.F.M., Medeiros R.M.T. \& Dantas A.J.A. 2008. Intoxicação por Mascagnia rigida (Malpighiaceae) em ovinos e caprinos. Pesq. Vet. Bras. 28:521-526. 